DOI: $10.31915 / N W S .2019 .19$

\title{
Az elektronikus szakirodalmi információforrások hazai lelöhelyadatbázisa, a COMPASS
}

\author{
Sütö Péter \\ MTA Könyvtár és Információs Központ EISZ Titkárság \\ (grid.496758.1)
}

\section{COMPASS, the database of scientific e-resources available in Hungary}

Hungarian university- and research libraries purchase most of their electronic scientific content in the framework of consortium-level agreements via Electronic Information Service National Programme (EISZ). Apart from acquisitions, it is also the goal of EISZ to ensure the utilisation of the available content for the wide community. For this reason, the development of COMPASS database was started in autumn 2016 in order to collect, organise, and make available the scientific databases and electronic documents purchased by the consortium or the institutions individually.

In September 2017, a newly developed version of COMPASS was launched on a new platform. The database provides multiple options for searching and interacting with scientific contents available in Hungary. In addition, it offers direct access to the databases for eligible users, as well as links to the full text of Open Access articles.

The paper covers how much the goals and plans of the project have been achieved, and describes the new functionalities and the experiences of the operation and usage since the database was launched.

Keywords: union catalogue, e-resources, electronic document delivery, open access

\section{Bevezetés}

Napjainkban a tudományos szakirodalom egyre nagyobb mértékben elektronikus formában jelenik meg, amely magával hozza a tudományos közösség igényét is az elektronikus formátumban rejlö elönyök iránt. Ez a folyamat Magyarországon is jól érzékelhető, a hazai felsőoktatási- és kutatóintézetek is nagyobb részt elektronikus formában szerzik be a szakirodalmat és teszik elérhetővé a felhasználóik számára. ${ }^{1}$

A hazai kutatóközösség szakirodalommal való ellátását az Elektronikus Információszolgáltatás Nemzeti Program segíti elö azzal, hogy lebonyolítja az elektronikus tudományos információforrások beszerzését konzorciumi keretek között a hazai felsőoktatási és non-profit kutatóintézetek számára. 2019-ben az EISZ programon keresztül több mint 230 intézmény szerzi be az elektronikus információforrásait, közel 180 adatbázist, e-folyóirat- és e-könyvcsomagot, ami azt jelenti, hogy többszázezer tudományos publikáció érhető el elektronikusan Magyarországon konzorciumi elöfizetések keretében.

1 Dér Ádám, Lencsés Ákos. Az EISZ Nemzeti Program szerepe a könyvtárak külföldi szakirodalommal való ellátásában. Tudományos és Müszaki Tájékoztatás 64, 5. sz. (2017): 241-246. 
Óriási lehetőségeket rejt magában ennek a hatalmas mennyiségü publikációnak a rendelkezésre állása, azonban felmerülnek a következő kérdések:

- Hogyan képesek ezt az információhalmazt a kutatók és a könyvtárosok áttekinteni és hatékonyan felhasználni?

- Hogyan tud ez az egyes intézményeken keresztül rendelkezésre álló forrás az ország teljes tudományos közössége számára hasznosulni?

Ezeket a kérdéseket az EISZ Titkárság munkatársai már 2016-ban is feltették maguknak és válaszként megszületett a COMPASS² továbbfejlesztésének terve, azaz egy országos elektronikusforrás lelőhelyadatbázis létrehozása.

\section{A fejlesztés céljai ${ }^{3}$}

A fejlesztés kezdetén, 2017. elején kiemelt célként fogalmaztuk meg, hogy a lelőhelyadatbázis segitse elő a szakirodalmi információkhoz való legális hozzáférés lehetőségének kiszélesitését, a források elérésének meggyorsitását, a hazai intézmények konzorciumi előfizetései mellett az egyéni előfizetéseik láthatóságát, mint fontos felhasználói szempontokat.

Természetesen a gyarapitási, fenntartói és tudományszervezési szempontok is hangsúlyosan megjelentek a célok között, úgymint a költséghatékonyság elösegitése, az országos tudományos tartalombeszerzés áttekinthetősége, a fejlesztésre szoruló területek feltérképezése és az intézményi kapcsolatokerősitése. Ezekkel a szempontokkal a COMPASS tervezett célja volt, hogy támogatást nyújtson akár stratégiai tervezési szinten a döntéselőkészitő folyamatokhoz is.

\section{A fejlesztés eredménye}

A célok elérése érdekében a már létező COMPASS felülethez egy PhP alapú MySQL adatbáziskezelőt használó keresömotort fejlesztettünk, amely a már meglévő szükös keresési lehetőségek ${ }^{4}$ (adatbázis, intézmény és település keresők) hatékonyságát jelentősen növelte és lehetővé tette a keresési lehetőségek kibővitését.

Figyelembe kellett ugyanis venni azt, hogy a felhasználók elsősorban az őket érdeklő folyóirat, vagy cikk adatainak vannak a birtokában, nem pedig annak, hogy az melyik adatbázisban érhető el. Tehát csak akkor müködhet hatékonyan a lelöhelyadatbázis, ha a címszintü keresési lehetőség is rendelkezésre áll.

A tervezés során a következő szint, a cikkre való keresés biztositása is felmerült, melyet a lehetőségek vizsgálata után a Crossref OpenURL használatának segitségével sikerült megvalósitani. Ez azt eredményezte, hogy a COMPASS-on

\footnotetext{
2 A COMPASS elérhetősége http://compass.mtak.hu

3 Dér Ádám, Nyiscsák Sándor. A COMPASS adatbázis új verziójának fejlesztése. (Networkshop 2017. Szeged) 2017. április 20. URL https://conference.niif.hu/event/7/session/5/contribution/52/material/slides/0.pdf

4 Páll Zoltán. COMPASS - Iránytü az információhoz (az MTA KIK EISZ új információszolgáltató adatbázisa). (Networkshop 2015, Eger) 2015. április 1. URL:

https://conference.niif.hu/event/3/session/14/contribution/80/material/slides/1.pdf
} 
keresztül lehetővé vált a keresés a DOI azonosítóval rendelkező publikációk közel teljes halmazára.

A lelőhelyadatbázis hatékonyságának kiteljesedését pedig a cikkszintű kereséshez kapcsolódóan az open access cikkek közvetlen hozzáférésének biztositása jelentette. Ez a funkció az Unpaywall (korábban oaDOI) API-n ${ }^{5}$ keresztül éri el a cikkek open access státuszára vonatkozó metaadatokat, amelyek automatikus feldolgozásával úgy a green, mint a gold open access cikkek teljes szöveghez vezető linkjei is megjelennek a COMPASS találati listájában. ${ }^{6}$

\section{Tapasztalatok a használati adatok tükrében}

A COMPASS jelenlegi verzióját 2017. szeptemberében élesitettük, azaz 1,5 év használati adatai állnak rendelkezésre.

A COMPASS jelenlegi tartalmának adatbázistípusok szerinti megoszlását (1. ábra) áttekintve jól látszik, hogy milyen nagy arányban kerültek be az intézmények egyéni előfizetései is az adatbázisba. Ez egyrészt mutatja azt, hogy jelentős mértékben sikerült bevonni az intézményeket a COMPASS tartalmi bövítésébe, egyúttal megerösíti azt a kezdeti célkitüzést, hogy a COMPASS tartalma nöjön túl a konzorciumi portfólión és törekedjen teljes országos lefedettségre.

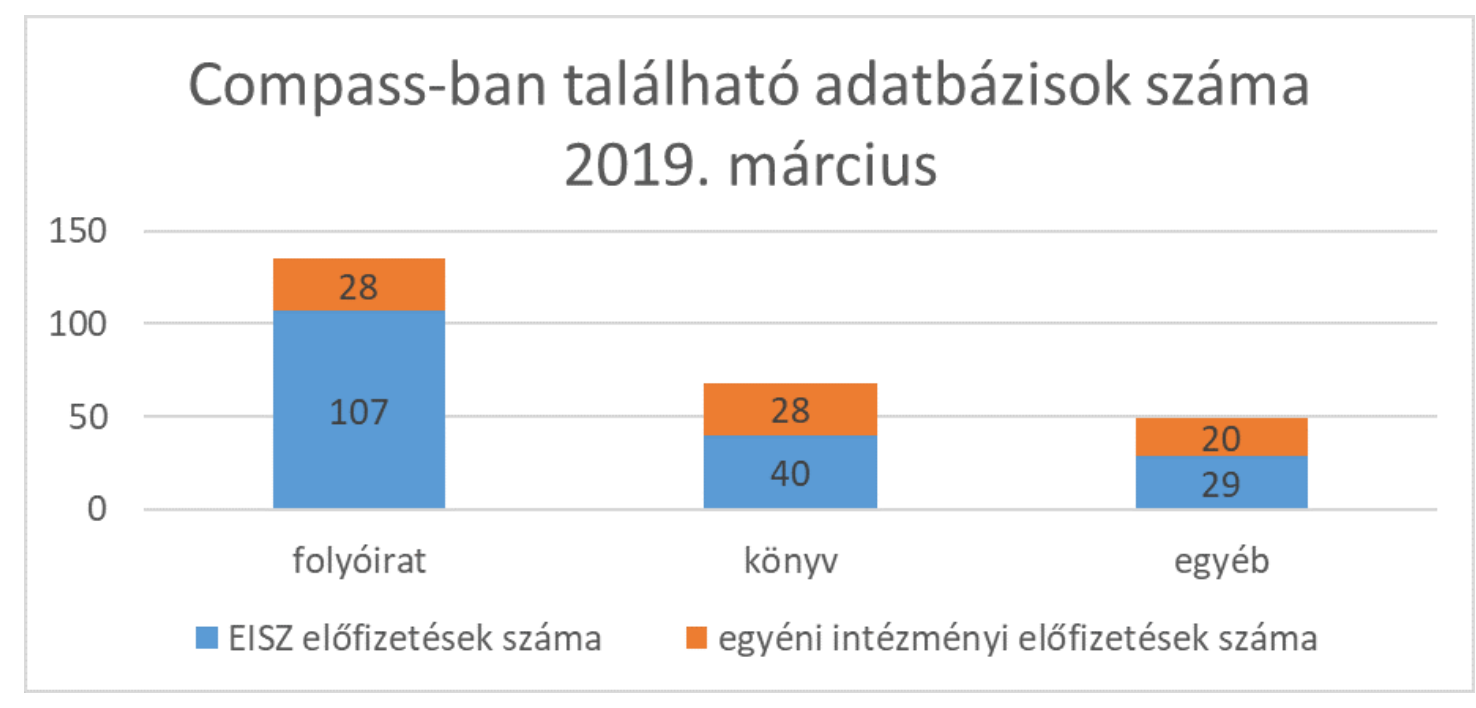

1. ábra: COMPASS-ban található adatbázisok száma, 2019. március

Mivel a COMPASS platform szabadon hozzáférhető mindenki számára ezért érdemes vizsgálni azt is, hogy honnan érkeznek a használatok (2. ábra). A célokkal összhangban azt tapasztaljuk, hogy a COMPASS-t az EISZ tagintézményeken kivüli IP tartományokból is nagy arányban használták, azaz lényegesen szélesebb használói kört ér el a lelöhelyadatbázis, mint a konzorciumi tagintézmények kutatói.

\footnotetext{
5 Az Unpaywall API elérhetösége http://unpaywall.org/products/api

6 Dér Ádám, Nyiscsák Sándor. A COMPASS adatbázis új verziójának fejlesztése. (Networkshop 2017. Szeged) 2017. április 20. URL:

https://conference.niif.hu/event/7/session/5/contribution/52/material/slides/0.pdf
} 
Használat intézmények szerinti megoszlása

2017. szeptember-2019. március

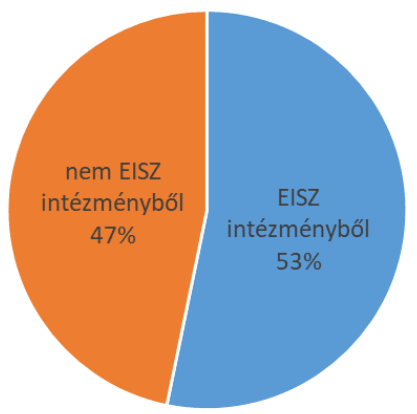

2. ábra: COMPASS használat intézmények szerinti megoszlása, 2017. szeptember - 2019. március

A COMPASS használata (3. ábra) az első 1,5 év alatt az elvárásoknak megfelelöen alakult. Nem meglepö, hogy a folyóirat/könyv cimre való keresés kimagaslik a többi keresési típus közül, hiszen a lelöhelyadatbázisnak ez az elsődleges funkciója. Egyúttal igazolja azt, hogy a fejlesztés egyik kulcs feladata volt a címszintü kereséssel való bővítés.

Azonban az adatok azt mutatják, hogy a cikkszintü keresések (DOI keresések) száma alacsony. Kutatói és könyvtáros visszajelzések alapján ennek lehetséges oka az, hogy a DOI használata, mint keresőkifejezés nem olyan kézenfekvő, mint egy folyóiratcím használata, még akkor sem, ha nem ugyanazon a szinten ad találatokat.

A DOI keresés alacsony használatából következik, hogy az Open Access cikk találatok száma is alacsony, és a részarányát tekintve is elmarad az Open Access cikkek globális arányától7. Ez rámutat arra, hogy mindenképpen növelni kell a felhasználók tudatosságát a cikkszintü keresésre.

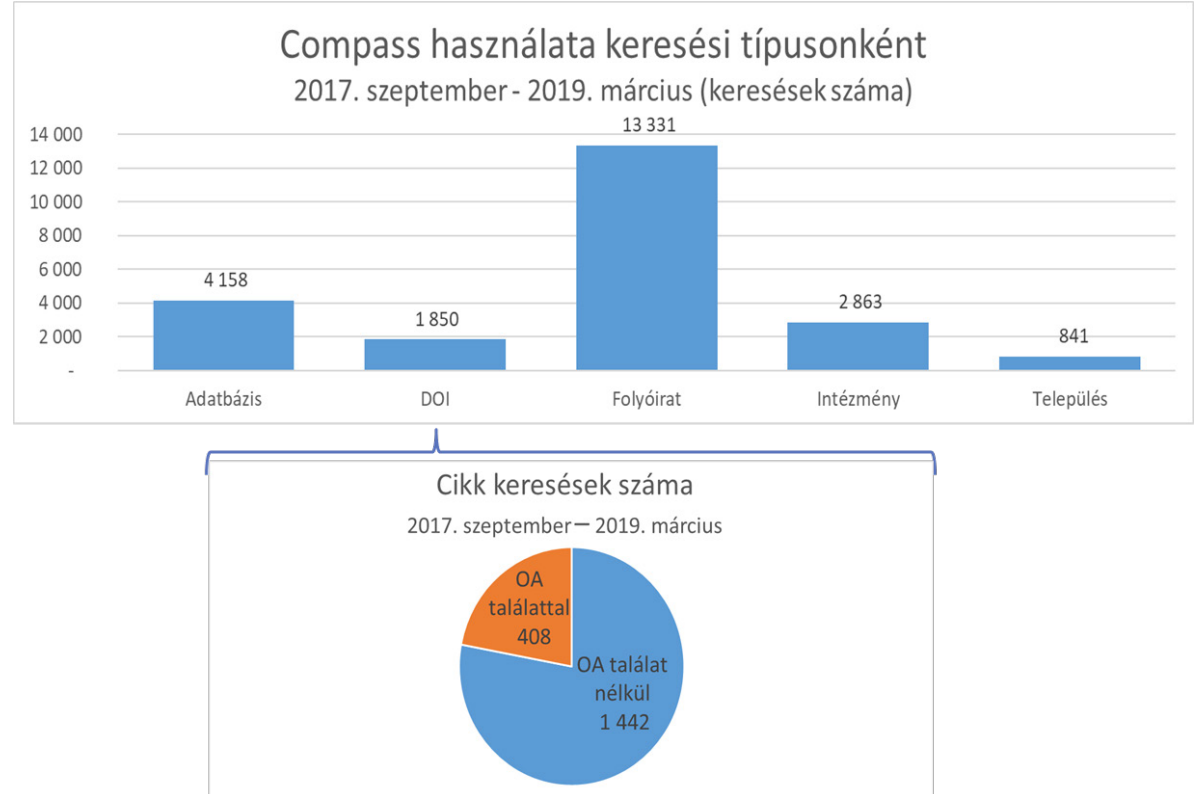

3. ábra: COMPASS használata keresési tipusonként, 2017. szeptember - 2019. március

$7 \quad$ Piwowar H. Priem J, Larivière V, Alperin JP, Matthias L, Norlander B, Farley A, West J, Haustein S: The state of OA: a large-scale analysis of the prevalence and impact of Open Access articles. PeerJ. 6:e4375 (2018) https://doi.org/10.7717/peerj.4375 
Ha megvizsgáljuk a keresések hatékonyságát (1. táblázat), azaz a találatot adó keresések számát, akkor a keresési típusok között nagy eltéréseket tapasztalunk. A DOI keresésnek nagyon magas a találati aránya, ami a DOI keresöbe beépitett intelligenciának köszönhetö, mely felismeri a keresőmezöbe bevitt karaktersorozatban a DOI azonositót. Az adatbázis és folyóirat keresések alacsonyabb hatékonysága viszont arra enged következtetni, hogy vagy a felhasználók figyelmetlenek a keresés során, vagy a felhasználói igények szélesebbek, mint a COMPASS lefedettsége.

1. táblázat: Találati hatékonyság ${ }^{8}$ keresési típusonként, 2017. szeptember - 2019. március

\begin{tabular}{|l|r|}
\hline DOI keresés & $91 \%$ \\
\hline Intézmény keresés & $91 \%$ \\
\hline Település keresés & $75 \%$ \\
\hline Folyóirat/könyv keresés & $61 \%$ \\
\hline Adatbázis keresés & $50 \%$ \\
\hline
\end{tabular}

Ahhoz, hogy jobban megismerjük az alacsonyabb keresési hatékonyság okait, elemeztük a sikertelen keresések keresési kifejezéseit a leggyengébb mutatóval rendelkező adatbázisra történő keresésnél (2. táblázat).

A vizsgálat során azt láttuk, hogy a sikertelen keresések 29\%-a a hibás keresés közvetlen megismétléséböl adódik, azaz a felhasználó újra lefuttatja változatlan keresőkifejezéssel ugyanazt a keresést, ami nem adott találatot, mert nem hiszi el, hogy nincs találat. Ezeket a duplumokat a hatékonyság vizsgálata szempontjából figyelmen kivül hagyhatjuk.

Az elirásból adódó sikertelen keresések alacsony aránya (2\%) feltételezhetően a kereső mezőbe beépitett automatikus kiegészitő (autocomplete) funkciónak köszönhető, ami mindenképpen igazolja ennek a fejlesztési elemnek a létjogosultságát.

Gyakori hiba (10\%), hogy az adatbázisra kereső fülön folyóiratra, esetleg intézményre keresnek a felhasználók, illetve hasonló félreértés a kiadókra való keresés (4\%). Ez részben figyelmetlenségből adódik, azaz a felhasználó elfelejt átkattintani a megfelelő fülre, másrészt félreértésböl, miszerint a kiválasztott fül nem az elérni kivánt eredményt, hanem a beírandó keresökifejezést specifikálja. Ezeken a mutatókon a keresöfelület felhasználókat segitő információinak pontosabb megjelenítésével, valamint a keresési algoritmus kiadóra és alternativ névre való kiszélesitésével várhatóan tudunk javitani.

$\overline{8}$ (az adott kereséstípus esetén találatot adó keresések száma) / (adott kereséstipus esetén lefuttatott összes keresés száma) 
A legnagyobb halmazt a hibás keresésék között a tárgyszóra történö keresés (34\%) teszi ki. Ez azt mutatja, hogy a felhasználók egy része nem lelőhelyadatbázisként, hanem egy általános tudományos információforrásként próbálja használni a COMPASS-t. Ezt a félreértést mindenképpen el kell oszlatni. A lelöhelyadatbázis célja nem az hogy szakirodalmat keressen általa a felhasználó a kutatásához, hanem az, hogy a már különböző forrásokban megtalált szakirodalmaknak megtalálja a magyarországi elérhetőségét, illetve amennyiben van nyiltt hozzáférésü elérhetősége, akkor biztositson közvetlen elérést a cikk teljes szövegéhez.

A COMPASS-ból hiányzó keresett adatbázisok egy része nem releváns adatbázisra történt keresés volt - például Matarka, ODR -, más részük pedig tényleg hiányzott az adott idöben az EISZ portfóliójából. Azonban sok közülük azóta már bekerült az elérhető adatbázisok körébe.

2. táblázat: Sikertelen adatbázisra történő keresések megoszlása a kereső kifejezések elemzése alapján, 2017. szeptember - 2019. március

\begin{tabular}{|l|r|}
\hline újrafuttatott keresés & $29 \%$ \\
\hline nem értelmezhető kifejezés & $0 \%$ \\
\hline elírás & $2 \%$ \\
\hline kiadóra keresés & $4 \%$ \\
\hline alternatív név & $4 \%$ \\
\hline más keresőmezőnek megfelelö kifejezés & $10 \%$ \\
\hline hiányzik az adatbázis a COMPASS-ból & $17 \%$ \\
\hline tárgyszó & $34 \%$ \\
\hline
\end{tabular}

\section{Felhasználói tapasztalatok}

A felhasználói tapasztalatok megismerése érdekében a partnerintézmények több mint 40 elektronikusforrás-menedzser könyvtárosával konzultáltunk és kaptunk visszajelzést közvetlenül a COMPASS egy elsödleges használói csoportjától.

Ennek során kiderült, hogy a könyvtári munka mely területein használják a COMPASS-t. A leghangsúlyosabb terület egyöntetüen a könyvtárközi kölcsönzés volt, míg meglepö módon az olvasószolgálat és a gyarapitás kevésbé jelentős felhasználási területek. Ez alapján úgy tünik, hogy a COMPASS elérte az intézményeket, de elsősorban az elektronikusforrás-menedzserek és a könyvtárközi kölcsönző kollégák ismerik, úgyhogy további idöt és energiát kell ráfordítani, hogy a Compass egy alapvető eszköz legyen minden hazai könyvtáros eszköztárában.

A felhasználói élményhez kapcsolódó visszajelzések alapján a kollégák a platformot könnyen kezelhetőnek tartják, továbbá a keresési lehetőségeket és a keresés hatékonyságát is nagyon jónak gondolják. Ez utóbbi ellentmond a korábban látott hatékonysági adatoknak, azonban feltételezhetö, hogy a sikertelen keresések nem a gyakorlott könyvtárosokhoz köthetők.

\footnotetext{
9 (az adott keresési hibával lefuttatott adatbázisra keresések száma) / (összes sikertelen adatbázisra keresés száma)
} 
Abban teljes volt az könyvtárosok egyetértése, hogy a COMPASS-nak ismertebbnek kellene lennie a könyvtáros és a kutatói közösségben egyaránt, amit az EISZ is fontos feladatának tart a jövöre nézve is.

\section{Összegzés}

A Magyarországon elérhető elektronikus tudományos információforrások mennyisége átlépte azt a kritikus tömeget, hogy a köztük lévö eligazodáshoz és a hatékony országos szintü hasznosulásukhoz szükségessé vált egy lelöhelyadatbázis létrehozása.

Az elektronikus források konzorciumi beszerzését lebonyolitó EISZ Titkárság által 2017-ben továbbfejlesztett nyilt hozzáférésü COMPASS platform lehetővé teszi a források lelöhelyének visszakeresését adatbázis, folyóirat/könyvcím, vagy cikk szinten egyaránt, továbbá nyiltt hozzáférésü cikktalálatok esetén a teljes szöveghez is közvetlen hozzáférést biztosit.

Az adatbázis használati adatainak elemzése rámutat arra, hogy a keresőplatform sokkal szélesebb használói kört ér el, mint az adatbázisokra előfizető intézmények kutatói és igazolta a fejlesztés egyik kulcselemének, a cimszintü keresésnek a fontosságát. A keresések hatékonyságvizsgálata segitett feltárni a még fejlesztendő elemeket, melyeken jelenleg is dolgozunk.

A könyvtáros felhasználói tapasztalatok pozitivak a könnyü kezelhetöség, a funkcionalitás és a hatékonyság szempontjából egyaránt, viszont szükséges a COMPASS ismertségének növelése, hogy egy mindennapos referensz eszköz legyen a könyvtárosok kezében és egy használt eszköze legyen a kutatóknak.

\section{Bibliográfia}

Dér Ádám, Lencsés Ákos. Az EISZ Nemzeti Program szerepe a könyvtárak külföldi szakirodalommal való ellátásában. Tudományos és Müszaki Tájékoztatás 64, 5. sz. (2017): 241-246.

Dér Ádám, Nyiscsák Sándor. A COMPASS adatbázis új verziójának fejlesztése. (Networkshop 2017, Szeged) 2017. április 20. URL: https://conference.niif.hu/ event/7/session/5/contribution/52/material/slides/o.pdf

Páll Zoltán. COMPASS - Iránytü az információhoz (az MTA KIK EISZ új információszolgáltató adatbázisa). (Networkshop 2015, Eger) 2015. április 1. URL: https://conference.niff.hu/event/3/session/14/contribution/80/material/ slides/1.pdf

Piwowar H, Priem J, Larivière V, Alperin JP, Matthias L, Norlander B, Farley A, West J, Haustein S. The state of OA: a large-scale analysis of the prevalence and impact of Open Access articles. PeerJ. 6:e4375 (2018) https://doi.org/10.7717/peerj.4375 